\title{
Genetic divergence among accessions of cassava (Manihot esculenta Crantz) sampled in the Tapajós region, State of Pará, using agronomic characters and microsatellite markers
}

\section{Divergência genética entre acessos de mandioca (Manihot esculenta Crantz) coletados na região do Tapajós, Estado do Pará, por meio de caracteres agronômicos e marcadores microssatélites}

\author{
Rodrigo de Souza Silva'; Elisa Ferreira Moura ${ }^{2 *}$; João Tomé de Farias Neto²; \\ Nelcimar Reis Sousa ${ }^{3}$; Mônika Fecury Moura' ${ }^{4}$ José Edson Sampaio ${ }^{5}$
}

\begin{abstract}
The aim of this work was to estimate the genetic divergence among accessions of cassava sampled in the Tapajós region in the State of Pará, Brazil, and conserved at the Regional Germplasm Bank of Eastern Amazon, using agronomic descriptors and molecular markers. Twenty-two accessions of cassava were evaluated in the field for two successive years, based on six agronomic descriptors in twelve-months-old plants without a specific experimental design. Accessions were also evaluated with eleven microsatellite loci in an automatic DNA analyser. Descriptive and multivariate statistical analyses were applied. Based on principal components analysis, the character weight of the aerial portion of the plant contributed most to the phenotypical variation. The six traits were used in the analysis of genetic dissimilarity between accessions, and the correlation between matrices generated by morphological and molecular data was estimated. The matrices of genetic dissimilarity were used in the construction of dendrograms using the UPGMA method. We observed a high variation of agronomical descriptors and molecular markers evaluated, which were capable to separate the accessions into distinct groups. A weak positive correlation was detected among the two matrices of genetic distances, which indicates the possibility to explore the genetic diversity using crossings and accessions Amarelinha 36 and Olho roxo 13 are divergent and potentially promising for the generation of heterotic hybrids.
\end{abstract}

Key words: Genetic distance. Multivariate analysis. Manihot esculenta.

\section{Resumo}

O objetivo deste trabalho foi estimar a divergência genética entre acessos de mandioca coletados na região do Tapajós no Estado do Pará e conservados no Banco Regional de Germoplasma da Amazônia Oriental por meio de descritores agronômicos e marcadores moleculares. Vinte e dois acessos de mandioca foram avaliados a campo por dois anos consecutivos com base em seis descritores agronômicos em plantas com doze meses de idade, sem o uso de delineamento experimental específico. Os acessos foram também avaliados com onze locos microssatélites em analisador de DNA automático. Foram realizadas as seguintes análises estatísticas: descritiva e multivariada. Com base na análise de componentes

\footnotetext{
${ }^{1}$ Discente do Curso de Mestrado do Programa de Pós-Graduação em Agronomia, Universidade Federal Rural da Amazônia, UFRA, Belém, PA, Brasil. Bolsista CAPES. E-mail: rodrigoitz@gmail.com

2 Pesquisadores, Empresa Brasileira de Pesquisa Agropecuária, Embrapa Amazônia Oriental, Belém, PA, Brasil. E-mail: elisa. moura@embrapa.br; joao.farias@embrapa.br

3 Pesquisadora, Embrapa Cocais, São Luis, MA, Brasil. E-mail: nelcimar.sousa@embrapa.br

${ }^{4}$ Bolsista de Pós-Doutorado CNPq do projeto 554337/2010-0, Embrapa Amazônia Oriental, Belém, PA, Brasil. E-mail: agromonika@yahoo.com.br

5 Técnico, Embrapa Amazônia Oriental, Belém, PA, Brasil. E-mail: jose.sampaio@embrapa.br

* Author for correspondence
} 
principais, o caráter peso da parte aérea da planta foi o que mais contribuiu para a variação fenotípica. Os seis caracteres foram utilizados nas análises de dissimilaridade genética e agrupamento, e foi estimada a correlação entre as matrizes geradas. As matrizes foram utilizadas para construção de dendrogramas pelo método UPGMA. Foi evidenciada ampla variação tanto dos descritores agronômicos quanto dos marcadores moleculares avaliados, os quais foram capazes de separar os acessos em grupos distintos. Foi encontrada fraca correlação entre as matrizes de distâncias genéticas, o que indicou a possibilidade de exploração da diversidade genética por meio de cruzamentos, sendo os acessos Amarelinha 36 e Olho roxo 13 divergentes e potencialmente promissores pare serem utilizados na geração de híbridos heterósticos.

Palavras-chave: Análise multivariada. Distância genética. Manihot esculenta.

\section{Introduction}

Cassava root (Manihot esculenta Crantz) is an important source of carbohydrates for almost one billion people in more than 100 tropical and subtropical countries (FAO, 2013). The species originated from South America, with Brazil as its probable centre of origin and domestication (LÉOTARD et al., 2009; OLSEN, 2004). The Amazon region is a reservoir of genetic resources of cassava. In Brazil, cassava is grown in all regions due to its capacity of edaphoclimatic adaptation. The state of Pará is the main producer of cassava, representing $21 \%$ of the national production; with the city of Santarém as the main root producer of the state (IBGE, 2013, 2015). Apart from studies about the genetic diversity of the species, very few efforts have been made to develop more productive varieties for the Northern region of Brazil, which may have contributed to the low cassava yield in this region, which is around $14900 \mathrm{~kg} \mathrm{ha}^{-1}$ per year (IBGE, 2015). Thus, one option to explore the available germplasm of cassava is to estimate the genetic divergence to predict promising crossings (KRISHNAMURTHY et al., 2013), which can be achieved using morphological, agronomic, and molecular markers.

Phenotypic traits are frequently used in the estimation of genetic divergence in cassava (AFONSO, 2013; NICK et al., 2008; VIEIRA et al., 2011). Among the phenotypic descriptors, the ones withagronomicimportancearemostinfluenced by the environment; however, they help to identify adapted accessions with productive potential (VIEIRA et al.,
2013). Molecular markers are also frequently used in the estimation of genetic divergence in cassava (ASARE et al., 2011; FERREIRA et al., 2008; SIQUEIRA et al., 2010), since they are not affected by the environment and are efficient in the detection of a large number of differences among accessions (KRISHNAMURTHY et al., 2013). However, they have the disadvantage of accessing all the genome and not only the regions expressing traits of agronomic importance (VIEIRA et al., 2011).

Currently, several marker techniques are available with several proposites, with the potential to be applied in various crops. Microsatellites, or SSR (simple sequence repeats) molecular markers, are co-dominant and highly polymorphic markers (SIQUEIRA et al., 2010) with a high abundance in plants (MBA et al., 2001); they are used in studies of genetic divergence.

The genetic cassava breeding program of Embrapa Eastern Amazon is based on activities carried out mostly in the state of Pará, with the aim to maintain accessions in the germplasm bank and to characterise and evaluate the accessions using different phenotypic and molecular characters. The estimative of genetic variability for a certain region allows to identify possible centres of diversity and to provide information about previously adapted genotypes in this region. Thus, the aim of this work was to estimate the genetic divergence among accessions of cassava sampled in the Tapajós region, Pará, and maintained in the Regional Germplasm Bank of the Eastern Amazon, using agronomic descriptors and molecular markers. 


\section{Material and Methods}

We used data obtained from phenotypic and molecular characterisation of 22 accessions of cassava sampled in the cities of Santarém and Belterra, Pará, and conserved in the Regional Germplasm Bank of Embrapa Eastern Amazon (Table 1). The bank is situated in the head-office of Embrapa Eastern Amazon, in the city of Belém, Pará (01 $27^{\circ}$ 'S latitude, and $48^{\circ} 30^{\prime} \mathrm{W}$ longitude). The average annual temperature of the region is $28^{\circ} \mathrm{C}$, average relative humidity $80 \%$, with an annual average precipitation of $2800 \mathrm{~mm}$ (INMET,
2009). The accessions were disposed in simple lines of nine plants, without an experimental design and a between-line and between-plant spacing of $1.0 \mathrm{~m}$. Accessions were regenerated when they reached an age of 12 to 14 months and cultured according to the recommendations of Souza et al. (2006). Phenotypic characterisation was performed using six quantitative agronomic traits measured for two consecutive years in the plants of each accession without borders, when plants were 12-months-old. The number of evaluated plants in the experimental plot, per accession and per year, varied from two to five (Table 1).

Table 1. List of the cassava (Manihot esculenta) accessions sampled in the Tapajós region in the State of Pará, Brazil, and conserved at the Regional Germplasm Bank of Eastern Amazon, with respective germplasm bank code, common name, municipality/state, and numbers of plants evaluated in the experimental plot.

\begin{tabular}{|c|c|c|c|c|c|}
\hline Number & Germplasm bank code & Common name & Municipality/State & $\mathrm{k} 1^{+}$ & $\mathrm{k} 2$ \\
\hline 1 & CPATU 304 & Abacatinha 3 & Santarém, PA & 3 & 2 \\
\hline 2 & CPATU 331 & Achada preta 50 & Santarém, PA & 5 & 3 \\
\hline 3 & CPATU 317 & Amarelinha 36 & Belterra, PA & 3 & 2 \\
\hline 4 & CPATU 332 & Amarelinha 47 & Santarém, PA & 5 & 5 \\
\hline 5 & CPATU 333 & Belterra 53 & Santarém, PA & 5 & 5 \\
\hline 6 & CPATU 305 & Bentivi 17 & Santarém, PA & 5 & 5 \\
\hline 7 & CPATU 351 & Bentivi 71 & Santarém, PA & 5 & 5 \\
\hline 8 & CPATU 334 & Boi branco 54 & Santarém, PA & 5 & 5 \\
\hline 9 & CPATU 306 & Boião & Santarém, PA & 5 & 5 \\
\hline 10 & CPATU 335 & Caratinga 1 & Santarém, PA & 5 & 5 \\
\hline 11 & CPATU 319 & Guia roxa 33 & Santarém, PA & 5 & 5 \\
\hline 12 & CPATU 337 & Inanu 46 & Santarém, PA & 5 & 5 \\
\hline 13 & CPATU 338 & Jararaca 59 & Santarém, PA & 5 & 5 \\
\hline 14 & CPATU 200 & M. Água Morna 10 & Santarém, PA & 5 & 5 \\
\hline 15 & CPATU 314 & Olho roxo 13 & Santarém, PA & 5 & 3 \\
\hline 16 & CPATU 325 & Ouricuri 37 & Belterra, PA & 4 & 4 \\
\hline 17 & CPATU 347 & Passarinhão grande 51 & Santarém, PA & 5 & 5 \\
\hline 18 & CPATU 348 & Roxinha 58 & Santarém, PA & 5 & 5 \\
\hline 19 & CPATU 355 & Saracurinha 69 & Santarém, PA & 5 & 5 \\
\hline 20 & CPATU 356 & 6 meses 70 & Santarém, PA & 5 & 5 \\
\hline 21 & CPATU 349 & Surubim 41 & Santarém, PA & 5 & 5 \\
\hline 22 & CPATU 329 & Tapajós 38 & Belterra, PA & 5 & 5 \\
\hline
\end{tabular}

${ }^{+}=\mathrm{k} 1$ and $\mathrm{k} 2$ : number of plants evaluated per useful experimental plot in the first and second years, respectively.

The following agronomical descriptors were evaluated, according to Fukuda and Guevara (1998): stem weight (SWP, kg), average root weight per plant (RWP, kg), number of roots per plant (NRP), number of rot roots per plant (NRRP), harvest index
(HI, \%), which refers to the value obtained after the ratio total root weight per total plant weight, according to Kawano (1990), and percentage of starch in the roots (PSR, \%), determined by hydrostatic balance, described by Grossman and 
Freitas (1950). The values obtained for SWP, RWP, NRP, NRRP, HI, and PSR were estimated based on the useful experimental plot for each evaluation year. The obtained data were analysed using descriptive statistical methods. Specifically, minimum and maximum values, average, amplitude of variation, and normality were estimated to describe the variability of agronomic descriptors. We used Shapiro-Wilk test at 5\% probability.

Median values of the two consecutive evaluation years (Table 2) were used for analysis of phenotypic correlation and application of principal components analysis and clustering. The phenotypic correlation among descriptors was estimated by the Spearman's correlation coefficient due to non-normalisation of data. We used the original values and a significance level with a $1 \%$ probability. The data of respective means were standardised because of different units of measurements of the descriptors, where the original mean $\mathrm{X}_{\mathrm{ij}}$ obtained for the $\mathrm{i}$-eth accession $(\mathrm{i}=1,2, \ldots \mathrm{p})$ referred to the $\mathrm{j}$-ieth descriptor $(\mathrm{j}=$ $1,2, \ldots, n)$ was divided by the standard deviation of the $\mathrm{j}$-ieth descriptor $(\mathrm{j}=1,2, \ldots, \mathrm{n})$, to generate the reduced mean $\mathrm{Z}_{\mathrm{ij}}$ of unique variance. The analyses were carried using the program R 3.2.2 (R CORE TEAM, 2013). Since evaluations did not follow any experimental design, determination of genetic distance among the 22 accessions was obtained with the mean Euclidean distance, using the software package GENES 5.1 (CRUZ, 2006).

Table 2. Non-standardised mean values of the descriptors stem weight (SWP), average root weight per plant (RWP), number of roots per plant (NRP), number of rot roots per plant (NRRP), harvest index (HI), and percentage of starch in the roots (PSR), evaluated for two successive years in cassava (Manihot esculenta) accessions sampled in the Tapajós region in the State of Pará, Brazil, and conserved at the Regional Germplasm Bank of Eastern Amazon.

\begin{tabular}{lccccccc}
\hline & & \multicolumn{7}{c}{ Agronomic descriptors } \\
\cline { 2 - 7 } Number & Accession & SWP & RWP & NRP & NRRP & HI & PSR \\
\hline & & Kg & Kg & --- Unit --- & $\%$ & $\%$ \\
1 & Abacatinha 3 & 2.27 & 3.60 & 6.00 & 0.00 & 60.85 & 29.71 \\
2 & Achada preta 50 & 2.26 & 5.51 & 8.50 & 0.00 & 67.30 & 31.68 \\
3 & Amarelinha 36 & 6.13 & 6.47 & 10.84 & 1.00 & 58.50 & 30.55 \\
4 & Amarelinha 47 & 2.78 & 2.94 & 5.40 & 0.00 & 56.79 & 29.43 \\
5 & Belterra 53 & 4.68 & 2.56 & 7.10 & 0.00 & 36.93 & 27.45 \\
6 & Bentivi 17 & 1.62 & 5.02 & 8.00 & 0.30 & 76.22 & 28.86 \\
7 & Bentivi 71 & 3.70 & 2.24 & 4.40 & 2.20 & 40.09 & 29.71 \\
8 & Boi branco 54 & 2.08 & 3.31 & 7.00 & 0.20 & 63.15 & 27.45 \\
9 & Boião & 3.44 & 4.16 & 8.10 & 0.00 & 58.24 & 30.84 \\
10 & Caratinga 1 & 2.92 & 2.86 & 7.40 & 0.00 & 52.51 & 29.14 \\
11 & Guia roxa 33 & 5.06 & 4.70 & 8.60 & 0.00 & 56.08 & 26.89 \\
12 & Inanu 46 & 2.68 & 2.86 & 8.30 & 0.00 & 53.00 & 27.17 \\
13 & Jararaca 59 & 4.28 & 3.86 & 7.40 & 0.00 & 51.80 & 28.58 \\
14 & M. Água Morna 10 & 0.78 & 2.39 & 6.10 & 0.00 & 74.51 & 30.84 \\
15 & Olho roxo 13 & 5.39 & 5.03 & 15.00 & 0.00 & 56.40 & 26.61 \\
16 & Ouricuri 37 & 0.65 & 1.48 & 4.63 & 0.00 & 71.94 & 26.89 \\
17 & Pasarinhão grande 51 & 5.02 & 3.00 & 9.20 & 0.00 & 42.44 & 30.27 \\
18 & Roxinha 58 & 2.60 & 2.96 & 8.00 & 0.20 & 59.21 & 29.43 \\
19 & Saracurinha 69 & 4.84 & 3.44 & 12.50 & 0.00 & 46.13 & 27.17 \\
20 & 6 meses 70 & 2.90 & 2.28 & 7.20 & 0.00 & 48.00 & 25.20 \\
21 & Surubim 41 & 4.06 & 3.38 & 9.90 & 0.10 & 49.37 & 26.32 \\
22 & Tapajós 38 & 2.96 & 3.28 & 7.20 & 0.00 & 53.47 & 29.99 \\
\hline
\end{tabular}


Total genomic DNA was extracted according to the procedure similar to the (DOYLE; DOYLE, 1990) described in Moura et al. (2013). DNA was quantified on $1 \%$ agarose gel using lambda phage DNA at different concentrations (50, 100, and 200 $\left.\mathrm{ng} \mu^{-1}\right)$ as a pattern. DNA was then diluted to $10 \mathrm{ng}$ $\mu 1^{-1}$.

Accessions were genotyped with 11 microsatellite loci (Table 2): SSRY89, SSRY93, and SSRY164 developed by Mba et al. (2001) and GA5, GA12, GA21, GA126, GA131, GA134, GA136, and GA140 developed by Chavarriaga-Aguirre et al.
(1998), described in Table 3. Amplification reagents contained $10 \mathrm{ng}$ of DNA, $100 \mu \mathrm{M}$ of each dNTP, $0.2 \mu \mathrm{M}$ of each primer, and $1.25 \mathrm{U}$ Taq polymerase (Invitrogen, São Paulo, Brazil) in 1X PCR buffer (50 mM KCl; $10 \mathrm{mM}$ Tris-HCl, pH 8.8, 0.1 \% Triton $\mathrm{X}-100 ; 1.5 \mathrm{mM} \mathrm{MgCl}_{2}$ ) at a total volume of $15 \mu \mathrm{l}$. Amplifications were conducted using a GeneAmp 9600 thermocycler (Applied Biosystems, Foster City, CA, USA) with the following program: an initial cycle of $94^{\circ} \mathrm{C}$ for $3 \mathrm{~min}$, followed by 40 cycles at $94^{\circ} \mathrm{C}$ for $30 \mathrm{~s}$, annealing temperature of each primer (Table 2) for $30 \mathrm{~s}$ and $72^{\circ} \mathrm{C}$ for $30 \mathrm{~s}$, and $72^{\circ} \mathrm{C}$ for $30 \mathrm{~min}$ for the final extension.

Table 3. Microsatellite loci used in the analysis of cassava (Manihot esculenta) accessions sampled in the Tapajós region in the State of Pará, Brazil, and conserved at the Regional Germplasm Bank of Eastern Amazon, with respective sequence and annealing temperature.

\begin{tabular}{|c|c|c|}
\hline Locus & Sequence $\left(5^{\prime}-3^{\prime}\right)$ & Annealing temperature $\left({ }^{\circ} \mathrm{C}\right)$ \\
\hline RY93 & $\begin{array}{l}\mathrm{F}^{*}: \text { TTTGTTGCTCACATGAAAACG } \\
\mathrm{R}^{* *}: \text { CAGATTCTTGTGGTGCGTG }\end{array}$ & 56 \\
\hline RY164 & $\begin{array}{l}\text { F: TCAAACAAGAATTAGCAGAACTGG } \\
\text { R: TGAGATTTCGTAATATTCATTTCACTT }\end{array}$ & 60 \\
\hline GA5 & $\begin{array}{l}\text { F: AATGTCATCGTCGGCTTCG } \\
\text { R: GCTGATAGCACAGAACACAG }\end{array}$ & 60 \\
\hline GA136 & $\begin{array}{l}\text { F: GTTGATAAAGTGGAAAGAGCA } \\
\text { R: ACTCCACTCCCGATGCTCGC }\end{array}$ & 59 \\
\hline GA126 & $\begin{array}{l}\text { F: GTGGAAATAAGCCATGTGATG } \\
\text { R: CCCATAATTGATGCCAGGTT }\end{array}$ & 60 \\
\hline RY89 & $\begin{array}{l}\text { F: AGTTGAGAAAACCTTGCATGAG } \\
\text { R: GGCTGTTCGTGATCCTTATTAAC }\end{array}$ & 58 \\
\hline GA131 & $\begin{array}{l}\text { F: TCCAGAAAGACTTCCGTTCA } \\
\text { R: CTCAACTACTGCACTGCACTC }\end{array}$ & 59 \\
\hline GA21 & $\begin{array}{l}\text { F: GCTTCATCATGGAAAAACC } \\
\text { R: CAATGCTTTACGGAAGAGCC }\end{array}$ & 58 \\
\hline GA12 & $\begin{array}{l}\text { F: ATTCCTCTAGCAGTTAAGC } \\
\text { R: CGATGATGCTCTTCGGAGGG }\end{array}$ & 59 \\
\hline GA134 & $\begin{array}{l}\text { F: CAATGTCCCAATTGGAGGA } \\
\text { R: ACCATGGATAGAGCTCACCG }\end{array}$ & 58 \\
\hline GA140 & $\begin{array}{l}\text { F: TCAAGGAAGCCTTCAGCTC } \\
\text { R: GAGCCACATCTACTCGACACC }\end{array}$ & 58 \\
\hline
\end{tabular}

${ }^{*} \mathrm{~F}=$ forward primer; ${ }^{* *} \mathrm{R}=$ reverse primer. 
PCRs were performed independently. A total of $1 \mu \mathrm{l}$ PCR volume was mixed with $8.75 \mu \mathrm{l} \mathrm{Hi-}$ Di formamide (Applied Biosystems) and $0.25 \mu \mathrm{l}$ of the marker of molecular size Liz-500 (Applied Biosystems) at $8 \mathrm{nM}$. This allowed genotyping in the DNA sequencer ABI PRISM 3500 (Applied Biosystems). Data collection and analysis were performed using GeneMapper v.4.1 (Applied Biosystems). The following genetic parameters were estimated: total (A) and average (A) number of alleles, observed $\left(\mathrm{H}_{\mathrm{O}}\right)$ and expected $\left(\mathrm{H}_{\mathrm{E}}\right)$ heterozygosities, number of private alleles (Ap), and coefficient of endogamy (F) (WEIR; COCKERHAM, 1984) for each locus and for the total of all loci. Analyses were carried out using GenAlEx 6.4.1 (PEAKALL; SMOUSE, 2012). We generated a matrix of genetic distances among each pair of accessions, using the coefficient of sharedalleles frequencies and the program PowerMarker 3.25 (LIU; MUSE, 2005).

Based on the genetic distances obtained with phenotypic and molecular analyses, we generated two dendrograms using the UPGMA method, which was submitted to the cut point based on the clustering analyses of package 'NbClust' of program R 3.2.2 (R CORE TEAM, 2013), using the procedure of Pseudot2 (CHARRAD et al., 2014). The adjustment of matrixes of genetic distances of the respective dendrograms was estimated by the coefficient of cophenetic correlation, according to Sokal and Rohlf (1962), and the correlation among the dendrograms was carried out with the test of Mantel based on 10,000 permutations (MANTEL, 1967), using program GENES 5.1 (CRUZ, 2006).

\section{Results and Discussion}

For each evaluation year, the interval of minimum and maximum values for SWP varied from 0.25 to 11.80 among the evaluated traits. Stem production is of particular importance since it indicates the production potential of propagative seeds, besides the use in animal feed (KVITSCHAL et al., 2003); cassava leaves are source of minerals, vitamins, and proteins (FREGENE et al., 2000; FAO, 2013). For the descriptors RWP and PSR, which determine the potential of starch production of the accessions (VIEIRA et al., 2013), the interval of minimum and maximum values varied from 0.80 to 12.0 and from 24.64 to 31.96 , respectively. NRP showed an interval of 2.60 to 26.0 , while NRRP showed an interval of minimum and maximum values of 0.0 to 4.40 , since part of the accessions showed null values of rot roots in the experimental plot (Table 2), which leads to the possibility of finding sources of tolerance to root rotting. However, NRRP is a trait with a high phenotypic plasticity and should be analysed carefully. HI, an important trait to evaluate root obtention, showed an interval of minimum and maximum values of 21.00 to 78.30 , when there is equilibrium between stem and root production (Table 4).

Table 4. Minimum, maximum and mean values, mean amplitude and normality test of six agronomic traits of 22 accessions of cassava collected in the Tapajós region, Pará, Brazil and kept on a germplasm bank in Eastern Amazon.

\begin{tabular}{lcccccc}
\hline Descriptors & Minimum & Maximum & Mean & $\begin{array}{c}\text { Amplitude of } \\
\text { means }\end{array}$ & $\begin{array}{c}\text { Standard } \\
\text { deviation }\end{array}$ & $\begin{array}{c}\text { Normality } \\
\text { test }^{*}\end{array}$ \\
\hline Stem weight of the plant & 0.25 & 11.80 & 3.32 & 11.55 & 3.00 & $0.84^{*}$ \\
Average root weight per plant & 0.80 & 12.00 & 3.52 & 11.20 & 2.46 & $0.87^{*}$ \\
Number of roots per plant & 2.60 & 26.00 & 8.04 & 23.40 & 5.13 & $0.86^{*}$ \\
Number of rot roots per plant & 0.00 & 4.40 & 0.18 & 4.40 & 0.72 & $0.27^{*}$ \\
Harvest index & 21.00 & 78.30 & 56.04 & 57.34 & 13.08 & $0.98^{\text {ns }}$ \\
Percentage of starch in the roots & 24.64 & 31.96 & 28.70 & 7.32 & 1.99 & $0.95^{\text {ns }}$ \\
\hline
\end{tabular}

${ }^{*}=$ Shapiro-Wilk test for normal distribution, where: ${ }^{*}=$ significant at $5 \%$ probability, indicates that the hypothesis for the normal distribution is rejected; ${ }^{n s}=$ non-significant. 
Thus, values of amplitude of means were higher than the values of means for all descriptors, except for PSR, which highlights the high variability for the agronomic descriptors (Table 4). Similar results were found by Vieira et al. (2013) who evaluated 16 accessions of cassava in the Brazilian Cerrado. High genetic variability in our study was expected, since the accessions were collected in an area supporting traditional culturein the state of Pará. According to LÉOTARD et al. (2009), the domestication of $M$. esculenta has occurred in the Amazon, which partly explains the variability identified in this region. None of the agronomic descriptors, except HI and PSR, did show normal distribution, since the Shapiro-Wilk test was significant at a $5 \%$ probability (Table 4 ).

Table 5 shows the values corresponding to Spearman's correlation among the six agronomical descriptors. Descriptor NRP showed a medium, positive and significant correlation with SWP $(\mathrm{r}=$ $\left.0.61^{* *}\right)$ and RWP $\left(r=0.70^{* *}\right)$. These correlations were expected, since the increase in root production is related to an increased stem mass and a larger number of roots (ALVES, 2006; ELIAS et al., 2001). On the other hand, SWP showed a medium and significantly negative correlation with $\mathrm{HI}\left(\mathrm{r}=-0.70^{* *}\right)$.

Table 5. Estimate of Spearman's correlation among the traits: stem weight of the plant (SWP), average root weight per plant (RWP), number of roots per plant (NRP), number of rot roots per plant (NRRP), harvest index (HI), and percentage of starch in the roots (PSR) of 22 accessions of cassava (Manihot esculenta) sampled in the Tapajós region in the State of Pará, Brazil, and conserved at the Regional Germplasm Bank of Eastern Amazon.

\begin{tabular}{cccccc}
\hline & SWP & RWP & NRP & NRRP & HI \\
\hline RWP & 0.30 & & & & \\
NRP & $0.61^{* *}$ & $0.70^{* *}$ & & & \\
NRRP & $-0.11^{\text {ns }}$ & $0.20^{\text {ns }}$ & $0.02^{\text {ns }}$ & & \\
HI & $-0.70^{* *}$ & $0.32^{\text {ns }}$ & $-0.12^{\text {ns }}$ & $0.23^{\text {ns }}$ & $0.12^{\text {ns }}$ \\
PSR & $-0.02^{\text {ns }}$ & $0.09^{\text {ns }}$ & $-0.16^{\text {ns }}$ & $0.05^{\text {ns }}$ & 0.06 \\
\hline
\end{tabular}

${ }^{* *}=$ significant at $1 \%$ probability ${ }^{n s}=$ non-significant.

The results of principal components analyses (PCA) are represented in Table 6 and Figure 1. PCA was used in order to identify the most important descriptors for the differentiation of accessions. Figure 1 represents the relation between each descriptor and the dispersal of cassava accessions, based on the first two principal components.

Table 6. Factor loading of the principal components analysis of 22 accessions of cassava (Manihot esculenta) sampled in the Tapajós region in the State of Pará, Brazil, and conserved at the Regional Germplasm Bank of Eastern Amazon, using six agronomic descriptors.

\begin{tabular}{lcccccc}
\hline Descriptors & PC 1 & PC 2 & PC 3 & PC 4 & PC 5 & PC 6 \\
\hline Stem weight of the plant & 0.63 & 0.12 & -0.14 & 0.15 & 0.26 & -0.68 \\
Average root weight per plant & 0.40 & -0.60 & -0.08 & -0.18 & 0.53 & 0.42 \\
Number of roots per plant & 0.60 & -0.21 & 0.29 & -0.10 & 0.73 & -0.12 \\
Number of rot roots per plant & 0.06 & 0.14 & -0.75 & -0.60 & -0.22 & 0.01 \\
Harvest index & -0.35 & -0.59 & 0.19 & -0.40 & -0.06 & -0.57 \\
Percentage of starch in the roots & -0.12 & -0.46 & -0.54 & -0.64 & -0.27 & -0.04 \\
& & & & & & \\
Eigenvalues: & 2.26 & 1.59 & 1.32 & 0.56 & 0.20 & 0.06 \\
\%Variance & & & & & & \\
\%Cumulative & 38.0 & 27.0 & 22.0 & 9.0 & 3.0 & 1.0 \\
\hline
\end{tabular}

$*$ = principal component. 
It is important to highlight the lack of correlation of the descriptor PSR with the descriptors directly related to root production (Figure 1). This lack of correlation based on phenotypic correlations is also shown in Table 5 and may indicate that the selection practiced by farmers of the Tapajós region is prioritised for stem and root production. It is worth noting that the city of Santarém represents the productive chain of cassava in the state of Pará. Thus, the evaluation of these materials allows the realisation of future genetic breeding efforts with the aim to select accessions adapted to the site of the culture.

Figure 1. The first and two principal components showing the relationship among the traits stem weight of the plant (SWP), average root weight per plant (RWP), number of roots per plant (NRP), number of rot roots per plant (NRRP), harvest index (HI), and percentage of starch in the roots (PSR) from the 22 accessions of cassava (Manihot esculenta) sampled in the Tapajós region in the State of Pará, Brazil, and conserved at the Regional Germplasm Bank of Eastern Amazon.

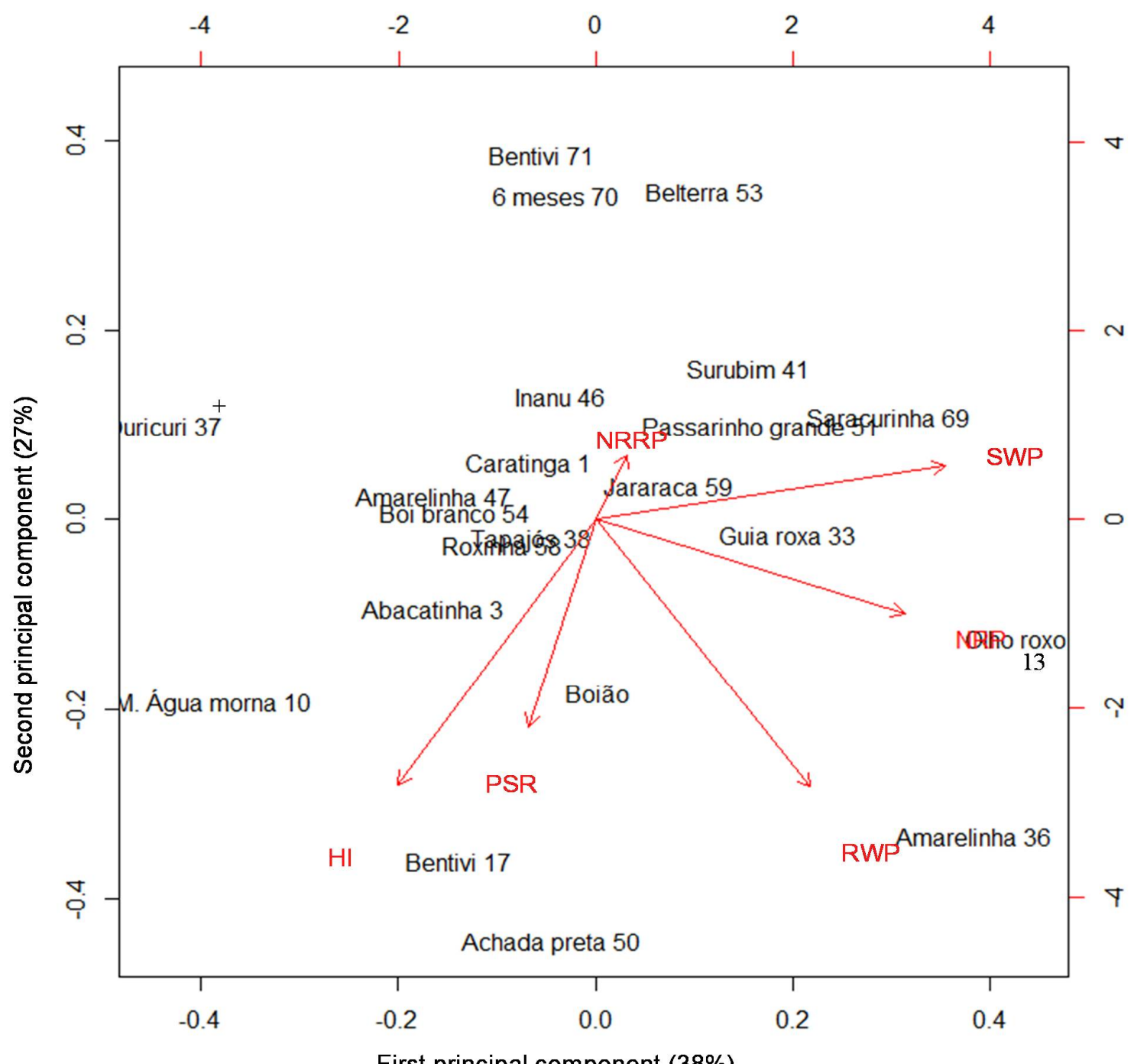

${ }^{+}=$Ouricuri 37 
The first two principal components explained $65 \%$ of the total variation in this study. The first principal component explained $38 \%$ of total variation, and the SWP showed high association with this component; however, it was important to discriminate the accessions Amarelinha 36 and Olho roxo 13 . The second principal component was responsible for $27 \%$ of variation, and RWP showed high association with the second component; it was important to discriminate the accessions Amarelinha 36 and Achada preta 50. HI also showed high association with the second principal component, and it was important to discriminate the accessions Bentivi 17, M. Água morna, and Ouricuri 37. PSR showed a higher association with the fourth principal component, which explained a lower portion of total variation ( $9 \%$ ); it was important to discriminate the accessions Achada preta 50, Boião, M. Água morna 10, and Amarelinha 36 (Table 6 and Figure 1).

It is worth mentioning that the importance of principal components decreases from the first to the last component, and the most important descriptors to measure genetic diversity are the ones with the highest coefficients of ponderation (eigenvector elements) in the components of higher eigenvalues; the last principal component explains a minimum fraction of total variation, showing the lower coefficients of ponderation in the components with a lower eigenvalue (JOLLIFFE, 1973). Thus, SWP was the trait which contributed most to the variability in this study. It had the highest coefficient of ponderation (0.63) associated with the highest eigenvalue of the first component (2.30), followed by NRP and RWP, respectively (Table 6). A study undertaken by Zuin et al. (2009) indicated that the descriptors with the highest contribution to genetic variability in cassava were average root size, petiole size, and average number of roots per plant.

The lower genetic distance based on the mean Euclidean distance was between accessions Caratinga 1 and Tapajós $38\left(\mathrm{~d}_{\mathrm{ij}}=0.23\right)$, which were grouped in the same cluster, and the most distant accessions were Bentivi 71 and Olho roxo 13 $\left(\mathrm{d}_{\mathrm{ij}}=2.90\right)$ (Figures 1 and 2). Nick et al. (2008), considering the graphical dispersion of 15 cassava accessions based on seven quantitative morphoagronomic descriptors, found a high genetic divergence among accessions. Based on the visual analysis of the dendrogram (Figure 2), using the Pseudot2 of 'NbClust' package of the R program, the accessions were grouped into six clusters. The first and largest cluster grouped 14 accessions, the second cluster grouped three accessions; followed by the third cluster with only two accessions and the fourth, fifth, and sixth clusters contained only one accession each: Amarelinha 36, Olho roxo 13 and Bentivi 71, respectively, representing the most divergent accessions. Amarelinha 36 had the highest means for SWP and RWP, the third highest mean for NRP, a mean value above $50 \%$ for $\mathrm{HI}$, and a mean value above $29 \%$ for PSR, but showed the second highest mean value for NRRP. Accession Olho roxo 13 had the highest mean value for NRP, the second highest mean values for SWP and RWP, besides a mean value above $50 \%$ for $\mathrm{HI}$ and zero mean for NRRP. On the other hand, accession Bentivi 17 showed the highest mean value for NRRP, the second lowest mean value for $\mathrm{HI}$, and the lowest mean value for NRP (Table 2).

The eleven loci amplified 67 alleles for the 22 accessions, with an average of 6.09 alleles per locus (Table 7). All loci were polymorphic. There was a variation of three (GA5 and GA136) to 11 alleles (RY93) per locus. The mean expected heterozygosity $\left(\mathrm{H}_{\mathrm{E}}\right)$ for all accessions was 0.65 and variation per locus ranged from 0.87 (RY93) to 0.42 (GA134). This value is below what was found in similar studies carried out in states of the North region (ELIAS et al., 2004; PERONI et al., 2007) and other regions of Brazil (SIQUEIRA et al., 2010; COSTA et al., 2013). However, this could be an effect of the number of accessions evaluated when compared to the other studies, where a higher number of accessions was analysed. The mean observed heterozygosity $\left(\mathrm{H}_{\mathrm{O}}\right)$ was 0.61 and varied from 1.0 (GA126) to 0.09 (RY89). The 
coefficient of endogamy was of 0.062 (Table 7). Some studies on cassava samples collected in the Brazilian Amazon also identified a small deficit of observed heterozygotes when compared to $\mathrm{H}_{\mathrm{E}}$, with a positive value for the coefficient of endogamy (ALVES-PEREIRA et al., 2011; MUHLEN et al., 2013). Alves-Pereira et al. (2011) argue that, since cassava is asexually propagated and genotypes are immediately fixed, it may restrict recombination.

Figure 2. Dendrogram of dissimilarity based on the mean Euclidean distance and UPGMA method of six agronomic descriptors for 22 accessions of cassava (Manihot esculenta) sampled in the Tapajós region in the State of Pará, Brazil, and conserved at the Regional Germplasm Bank of Eastern Amazon; coefficient of cophenetic correlation $(\mathrm{r}=0.80)$.

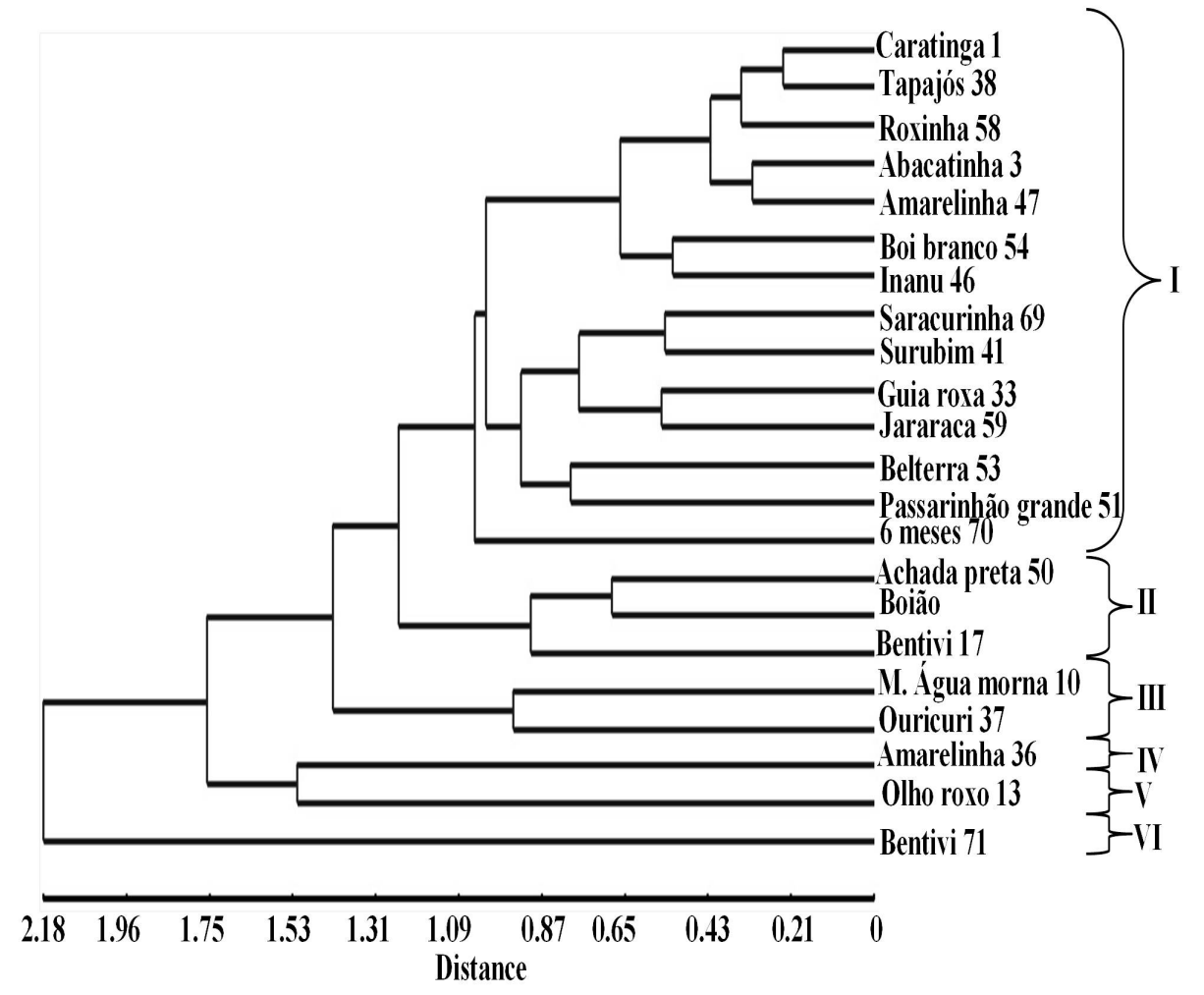

The most genetically close accessions were Boi branco 54 and Jararaca $59\left(\mathrm{~d}_{\mathrm{ij}}=5\right)$, which grouped in the same cluster in the dendrogram, and the least similar were Bentivi 17 and Bentivi $71\left(\mathrm{~d}_{\mathrm{ij}}=31\right)$ (Figure 3). When considering the Pseudot2 method of package 'NbClust' ( $\mathrm{R}$ program) as cut point, the accessions were grouped in two major clusters, with six distinct subclusters (Figure 3). The number of accessions allocated in the subgroups varied from one to seven, and the first subcluster was the largest one with seven accessions, followed by the second, third, and fifth subcluster with four accessions each, the sixth subcluster with two accessions and the fourth with only one accession: Olho roxo 13, which had a high genetic divergence. It is worth noticing that accession Olho roxo 13 was also the most divergent one in the agronomic analysis (Figure 2). Siqueira et al. (2010), when investigated the structure and genetic diversity of 83 accessions of cassava sampled in the Brazilian Cerrado using nine microsatellite markers, they also identified two major clusters using the UPGMA method with well-defined subclusters of accessions. Asare et al. (2011) found a similar result when they quantified the genetic diversity of 43 accessions of cassava using 20 SSR loci. 
Table 7. Genetic diversity parameters estimated based on the genotyping of 22 accessions of cassava (Manihot esculenta) sampled in the Tapajós region in the State of Pará, Brazil, and conserved at the Regional Germplasm Bank of Eastern Amazon. Eleven microsatellite loci and their respective number of alleles (A); observed and expected heterozygosity $\left(\mathrm{H}_{\mathrm{O}}\right.$ and $\left.\mathrm{H}_{\mathrm{E}}\right)$; and coefficient of endogamy $(\mathrm{F})$.

\begin{tabular}{lccccc}
\hline \multicolumn{1}{c}{ Locus } & Amplitude of alleles (in base pairs) & $\mathrm{A}$ & $\mathrm{H}_{\mathrm{F}}$ & $\mathrm{H}_{\mathrm{O}}$ & $\mathrm{F}$ \\
\hline RY93 & $265-287$ & 11 & 0.874 & 0.909 & -0.040 \\
RY164 & $160-184$ & 6 & 0.620 & 0.636 & -0.027 \\
GA5 & $114-123$ & 3 & 0.434 & 0.550 & -0.268 \\
GA136 & $148-154$ & 3 & 0.495 & 0.545 & -0.102 \\
GA126 & $176-214$ & 10 & 0.861 & 1.000 & -0.162 \\
RY89 & $100-118$ & 5 & 0.519 & 0.095 & 0.817 \\
GA131 & $92-113$ & 10 & 0.822 & 0.636 & 0.226 \\
GA21 & 5 & 0.671 & 0.500 & 0.255 \\
GA12 & $102-111$ & 5 & 0.771 & 0.579 & 0.250 \\
GA134 & $132-142$ & 4 & 0.422 & 0.524 & -0.242 \\
GA140 & $307-327$ & 5 & 0.686 & 0.700 & -0.020 \\
\hline Mean & $155-169$ & & 0.65 & 0.61 & 0.062 \\
\hline
\end{tabular}

Figure 3. Dendrogram obtained based on the shared-allele frequencies distance and UPGMA method of clustering based on 11 microsatellite markers of 22 accessions of cassava (Manihot esculenta) sampled in the Tapajós region in the State of Pará, Brazil, and conserved at the Regional Germplasm Bank of Eastern Amazon; coefficient of cophenetic correlation $(\mathrm{r}=0.76)$.

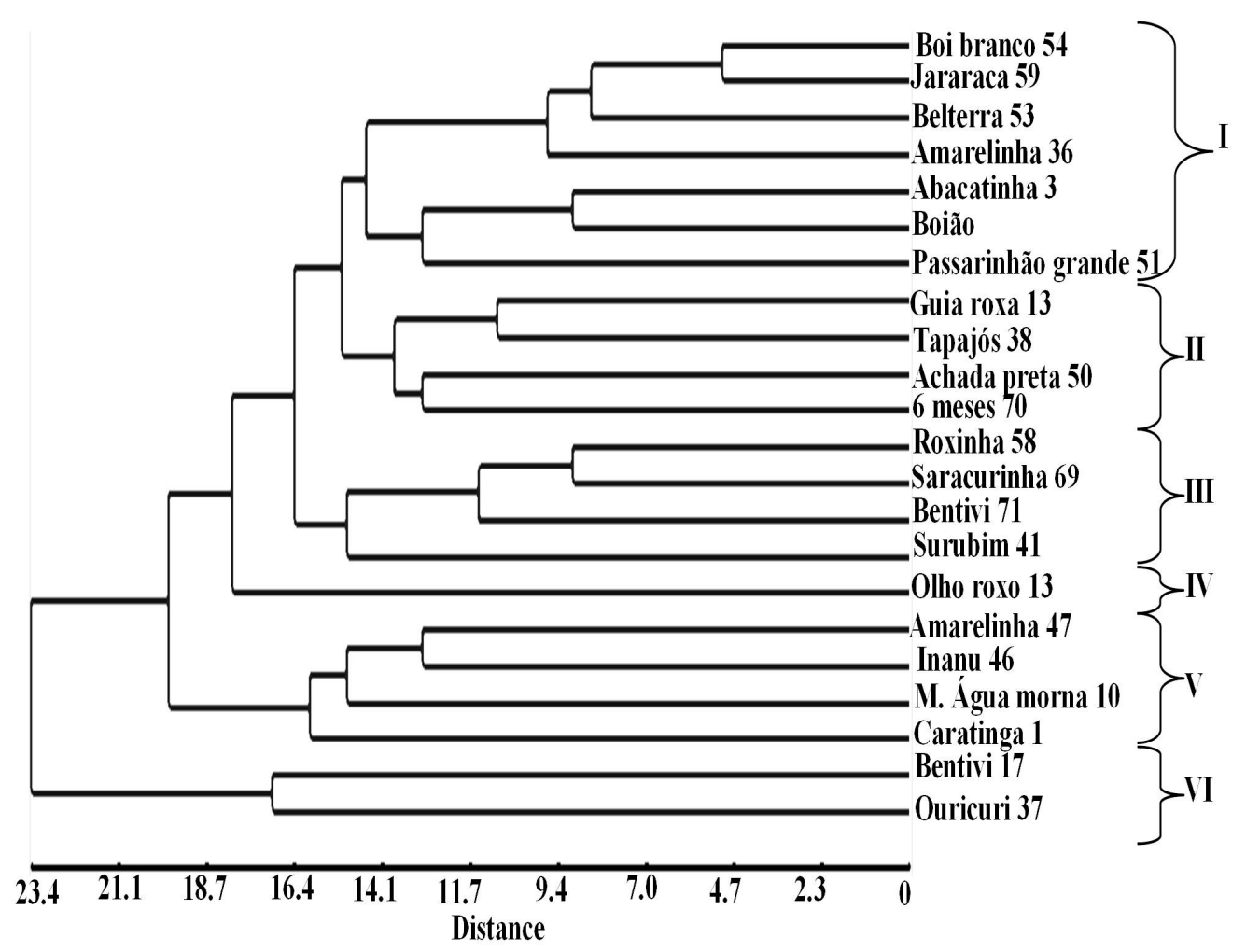


Molecular analysis confirmed the genetic similarity between the accessions Boi branco 54 and Jararaca 59, once they got allocated in the same cluster on the dendrogram based on agronomic data, cluster I, as well as the genetic dissimilarity among the accessions Bentivi 17 and Bentivi 71, clusters II and VI on the dendrogram of agronomic data, respectively. However, Tapajós 38 and Caratinga 1 , the most genetically close accessions based on agronomic data, on cluster I, were genetically distant by molecular analysis, and allocated in different sub clusters II and V, respectively, as well as accessions M. Água morna 10 and Ouricuri 37, which were genetically close based on agronomic data, in cluster III, but were genetically distant considering molecular characterisation, and were allocated in sub clusters V and VI, respectively (Figures 2 and 3). Accessions genetically close, based on the agronomic analysis, were genetically distant based on molecular analysis. Vieira et al. (2011) characterised 16 accessions of cassava of the Germplasm Bank of Cerrado, using agronomic, morphological and RAPD molecular markers, also identified low genetic similarity of accessions by molecular analysis when compared to agronomic and morphological analyses.

Accession M. Água morna 10 belongs to the class of sweet cassavas, or 'macaxeira', which may justify the molecular distinction from accession Ouricuri 37. However, the fact that the variation detected by molecular markers is not the adaptive type and not affected by natural or artificial selection (VIEIRA et al., 2007), may have influenced the separation of accessions by molecular analysis. Thus, the pressure of artificial or natural selection used in the Tapajós region may have influenced the genetic similarity of accessions based on agronomic analysis. It is important to mention that farmers realise recurrent cultures for long periods using artificial selection of the most promising materials, with the best agronomic traits, mostly root production. Besides, discrimination and selection of cassava plants based on morphological traits in the field are very common.

The coefficients of cophenetic correlation of both dendrograms revealed fine adjustments between the graphic representations of phenotypic and molecular genetic distances and the matrixes generated by the distances, confirming the inferences based on graphic visualisations on Figures $2(\mathrm{r}=$ $0.80)$ and $3(r=0.76)$. Asare et al. (2011) identified the following values of coefficients of cophenetic correlation: $r=0.84$ and $r=0.85$, respectively. In addition, Vieira et al. (2011) identified values of coefficient of cophenetic correlation of 0.75 and 0.95 , respectively. These authors used 66 markers of the RAPD type.

The statistics of Mantel $(r=0.058)$ indicated a weak correlation between matrixes with $\mathrm{P}>0.05$ (Figure 4), which shows independence between matrixes. Vieira et al. (2013) analysed accessions of cassava using quantitative and qualitative phenotypic descriptors and molecular markers; they identified reduced or null correlations among matrixes of genetic distances generated by individual analyses. On the other hand, they found significant correlations between the matrix of genetic distance generated by the joint analysis with matrixes generated by qualitative $\left(\mathrm{r}=0.52^{*}\right)$ and molecular analyses $\left(\mathrm{r}=0.75^{*}\right)$. These authors showed the possibility to use a joint dissimilarity index parallel to individual analyses of dissimilarities, which can be an important tool in studies of conservation and use of cassava germplasm. However, it is important that molecular and phenotypic analyses are realised independently in order to obtain a more complete knowledge of the level of genetic divergence among accessions (VIEIRA et al., 2007). In addition, Krishnamurthy et al. (2013) evaluated 35 accessions of pepper using morphological descriptors and AFLP markers; they also identified low magnitude correlations among the matrixes of genetic distances $(r=0.041 ; \mathrm{P}>0.05)$. 
Figure 4. Scatter plot of the correlation between molecular distance matrix and phenotypic distance matrix of the 22 accessions of cassava (Manihot esculenta) sampled in the Tapajós region in the State of Pará, Brazil, and conserved at the Regional Germplasm Bank of Eastern Amazon.

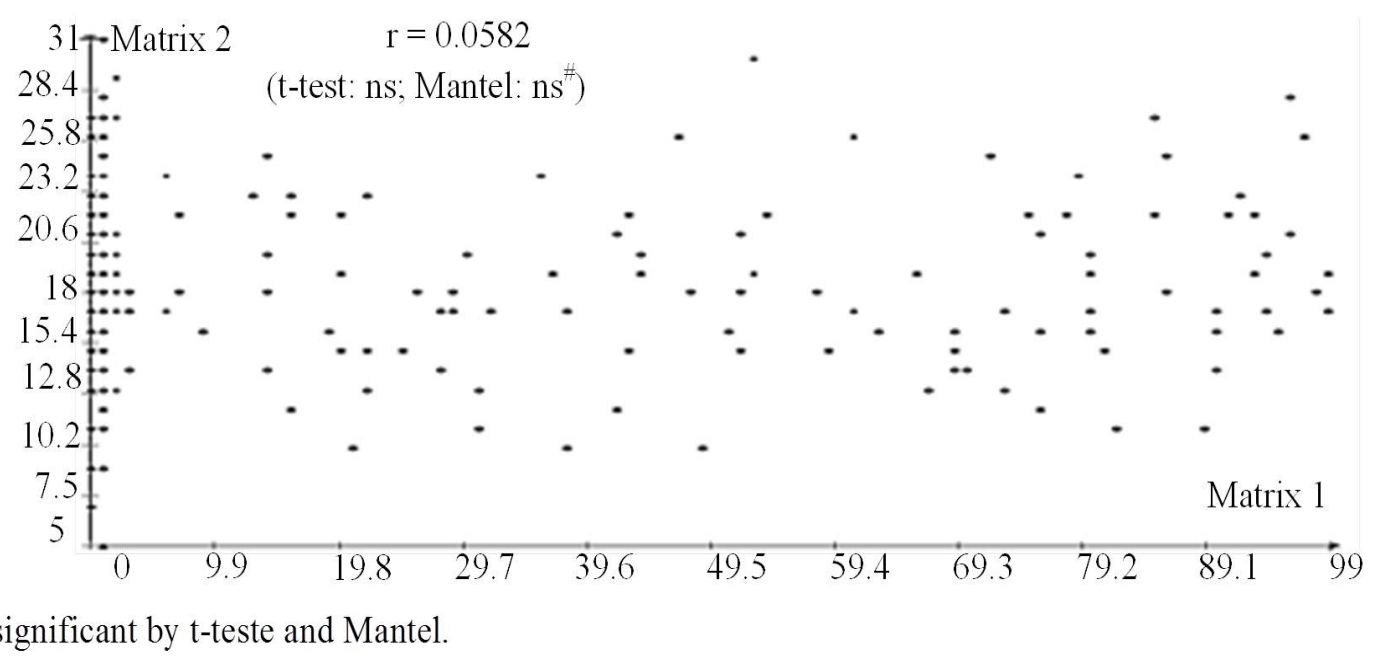

Thus, once there was a low Mantel correlation and traits used for future selection efforts will be the agronomic ones, it was given more emphasis to the analyses using dissimilarity matrix generated by the mean Euclidean distance (Figures 1 and 2). In the genetic breeding process, the heterosis of importance is the one linked to the trait under selection. Thus, based on the dendrogram generated by the matrix of mean Euclidean distances (Figure 2), accessions Amarelinha 36 and Olho roxo 13 were the most promising ones for possible crossings to explore heterosis; they were the most divergent ones when compared to the other accessions. Granja et al. (2009) and Nick et al. (2008) highlight that accessions with higher levels of genetic divergence may be used in hybridization programs, since the trait under selection is present or superior in both genitors.

We identified the following potential crossings: Amarelinha 36x Olho roxo 13, Amarelinha 36 x Guia roxa 33, and Olho roxo $13 \times$ Achada preta 50. There is also the possibility of introducing accessions with high starch contents, as we identified average values of starch in the roots above $29 \%$, especially with the crossings Amarelinha 36 x Achada preta 50 and Amarelinha 36 x Boião (Table 2 and Figure 2). It is worth noting that, for a more reliable interpretation of the genetic distances among the selected accessions, new efforts of characterisation may be performed in the field, considering the analyses per se of pairs indicated for crossing. Krishnamurthy et al. (2013) emphasise that the genetic diversity is necessary to obtain significant levels of heterosis; however, this is not enough to be successful. Thus, the selected accessions may be divergent among each other, but not necessarily complementary for desirable traits (NICK et al., 2010).

It is important to highlight that both agronomic traits and microsatellite markers were capable to separate accessions into distinct clusters, representing the genetic diversity among accessions in the two analyses. Thus, low genetic similarity was verified, which indicates differences of genetic origin among the evaluated accessions, even though they were sampled in the same micro-region of the state of Pará. This genetic diversity in the region is probably a result of the reproduction system of the species, which consists of spontaneous germination of seeds, self-pollination, and mixed reproduction (ELIAS et al., 2001; CEBALLOS et al., 2004), besides gene flow generated by exchanges of materials among farmers, specially made by asexual 
reproduction (FARALDO et al., 2000) and recurrent culture of accessions with artificial selection.

Thus, this study estimates the genetic and phenotypic variability identified for cassava conserved in farms within a region which traditionally grows cassava to produce 'farinha'. Besides, it represents new possibilities of genetic breeding efforts for this particular region, using potential crossings between already adapted materials, with the aim to improve root productivity and the incorporation of accessions with high starch contents.

\section{Conclusions}

The 22 accessions of cassava sampled in the Tapajós region, Pará, and belonging to the Regional Germplasm Bank of Eastern Amazon, have a wide genetic variability considering the agronomic and molecular traits evaluated.

Both agronomic and molecular descriptors allow separation of accessions in distinct clusters and identification of the accession Olho roxo 13 as the most divergent one.

The weak correlation among the matrixes of genetic distances (agronomic and molecular) enabled, based on agronomic analysis, the identification of crossings: Amarelinha $36 \mathrm{x}$ Olho roxo 13, Amarelinha $36 \times$ Achada preta 50, Amarelinha 36 x Boião, Amarelinha 36 x Guia roxa 33 and Olho roxo $13 \times$ Achada preta 50 to be tested on genetic breeding programs.

\section{Acknowledgments}

The authors thank CAPES, to $\mathrm{CNPq}$ (process 408042/2013-3), to Embrapa (Project 010601071409), to FAPESPA (ICAAF 145/2014) and to the Federal Rural University of Amazonia for the support for activities.

\section{References}

AFONSO, S. D. J. Seleção de descritores morfológicos e divergência genética em acessos de mandioca. 2013. Dissertação (Mestrado em Recursos Genéticos Vegetais) - Universidade Federal do Recôncavo da Bahia, Cruz das Almas.

ALVES, A. A. C. Fisiologia da mandioca. In: SOUZA, L. S.; FARIAS, A. R. N.; MATTOS, P. L. P.; FUKUDA, W. M. G. Aspectos socioeconômicos e agronômicos da mandioca. Cruz das Almas: CNPMF, 2006. p. 138-169.

ALVES-PEREIRA, A.; PERONI, N.; ABREU, A. G.; GRIBEL, R.; CLEMENT, C. R. Genetic structure of traditional varieties of bitter manioc in three soils in Central Amazonia. Genetica, Dordrecht, v. 139, n. 10, p. 1259-1271, 2011.

ASARE, P. A.; GALYUON, J. K.; SARFO, J. K.; TETTEH, J. P. Morphological and molecular based diversity studies of some cassava (Manihot esculenta Crantz) germoplasm in Ghana. African Journal of Biotechnology, Nairobi, v. 10, n. 63, p. 13900-13908, 2011.

INSTITUTO BRASILEIRO DE GEOGRAFIA E ESTATÍSTICA - IBGE. Levantamento sistemático da produção agrícola (LSPA): pesquisa mensal de previsão e acompanhamento das safras agrícolas no ano civil. Rio de Janeiro: IBGE, 2015. Available at: <ftp://ftp.ibge. gov.br/Producao_Agricola/Levantamento_Sistematico da_Producao_[mensal]/Fasciculo/lspa_201501.pdf $>$. Accessed at: 24 maio 2015.

Sistema IBGE de recuperação automática SIDRA. Previsão de Safra. Rio de Janeiro: IBGE, 2013. Available at: $<$ http: //www.sidra.ibge.gov.br $>$. Accessed at: 17 jul. 2015.

INSTITUTO NACIONAL DE METEOROLOGIA INMET. Normas climatológicas do Brasil. Brasília: INMET, 2009. Available at: <http://www.inmet.gov. br/portal/index.php? $\mathrm{r}=$ clima/normaisClimatologicas $>$. Accessed at: 10 mar. 2015.

CEBAllos, H.; IGlesias, C. A.; PÉREZ, J. C.; DIXON, A. G. O. Cassava breeding: opportunities and challenges. Plant Molecular Biology, Dordrecht, v. 56, n. 4, p. 503-516, 2004.

CHARRAD, M.; GHAZZALI, N.; BOITEAU, V.; NIKNAFS, A. NbClust: an R package for determining the relevant number of clusters in a data set. Journal of Statistical Software, Los Angeles, v. 61, n. 6, p. 1-36, 2014. 
CHAVARRIAGA-AGUIRRE, P. P.; MAYA, M. M.; BONIERBOLE, M. W.; KRESOVICH, S.; FREGENE, M. A.; TOHME, J.; KOCHERT, G. Microsatellites in cassava (Manihot esculenta Crantz): discovery, inheritance and variability. Theoretical and Applied Genetics, Berlin, v. 97, n. 3, p. 493-501, 1998.

COSTA, T. R.; VIDIGAL-FILHO, P. S.; GONÇALVESVIDIGAL, M. C.; GALVÁN, M. Z.; LACANALLO, G. F.; SILVA, L. I.; KIVISCHAL, M. V. Genetic diversity and population structure of sweet cassava using simple sequence repeat (SSR) molecular markers. African Journal of Biotechnology, Nairobi, v. 12, n. 10, p. 10401048, 2013.

CRUZ, C. D. Programa Genes: análise multivariada e simulação. Viçosa, MG: UFV, 2006. 175 p.

DOYLE, J. J.; DOYLE, J. L. Isolation of plant DNA from fresh tissue. Focus, Richmond, v. 12, n. 1, p. 13-15, 1990.

ELIAS, M.; MCKEY, D.; PANAUD, O.; ANSTETT, M. C.; ROBERT, T. Traditional management of cassava morphological and genetic diversity by the Makushi Amerindians (Guyana, South America): perspectives for on-farm conservation of crop genetic resources. Euphytica, Wageningen, v. 120, n. 1, p. 143-157, 2001.

ELIAS, M.; MUHLEN, G. S.; MCKEY, D.; ROA, A. C.; TOHME, J. Genetic diversity of traditional South American landraces of cassava (Manihot esculenta Crantz): an analysis using microsatellites. Economic Botany, Bronx, v. 58, n. 2, p. 242-256, 2004.

FARALDO, M. I. F.; SILVA, R. M.; ANDO, A.; MARTINS, P. S. Variabilidade genética de etnovariedades de mandioca em regiões geográficas do Brasil. Scientia Agrícola, Piracicaba, v. 57, n. 3, p. 499-505, 2000.

FERREIRA, C. F.; ALVES, E.; PESTANA, K. N.; JUNGHANS, D. T.; KOBAYASHI, A. K.; SANTOS, V. J.; SILVA, R. P.; SILVA, P. H.; SOARES, E.; FUKUDA, W. M. G. Molecular characterization of cassava (Manihot esculenta Crantz) with yellow-orange roots for beta-carotene improvement. Crop Breeding and Applied Biotechnology, Viçosa, MG, v. 8, n. 1, p. 23-29, 2008.

FREGENE, M.; BERNAL, A.; DUQUE, M.; DIXON, A.; TOHME, J. AFLP analysis of African cassava (Manihot esculenta Crantz) germplasm resistant to the cassava mosaic disease (CMD). Theoretical and Applied Genetics, Berlin, v. 100, n. 5, p. 678-685, 2000.

FUKUDA, W. M. G.; GUEVARA, C. L. Descritores morfológicos e agronômicos para a caracterização de mandioca (Manihot esculenta Crantz). Cruz das Almas: CNPMF, 1998. 38 p.
GRANJA, M. M. C.; MELO-FILHO, P. A.; SANTOS, R. C. Análise genética em uma população intraespecífica de amendoim baseada em descritores fenotípicos. Revista Brasileira de Ciências Agrárias, Recife, v. 4, n. 3, p. 257 260, 2009.

GROSSMAN, J.; FREITAS, A. C. Determinação do teor de matéria seca pelo peso específico em raízes de mandioca. Revista Agronômica, Porto Alegre, v. 14, n. 160/162, p. 75-80, 1950.

JOLLIFFE, I. T. Discarding variables in a principal component analysis. II. Real data. Journal of the Royal Statistical Society. Applied Statistics, Malden, v. 22, n. 1, p. 21-31, 1973.

KAWANO, K. Harvest index. In: FUKUDA, W. M. G.; GUEVARA, C. L.; KAWUKI, R.; FERGUSON, M. E. Selected morphological and agronomic descriptors for the characterization of cassava. Ibadan: International Institute of tropical Agriculture - IITA, 1990. p. 13-14.

KVITSCHAL, M. V.; VIDIGIAL-FILHO, P. S.; PEQUENO, M. G.; SAGRILO, E. S.; BRUMATI, C. C.; MANZOTI, M.; BEVILAQUA, G. Avaliação de clones de mandioca (Manihot esculenta Crantz) para indústria na região Noroeste do Estado do Paraná. Acta Scientiarum Agronomy, Maringá, v. 25, n. 2, p. 299-304, 2003.

KRISHNAMURTHY, S. L.; RAO, A. M.; REDDY, K. M.; RAMESH, S.; HITTALMANI, S.; RAO, M. G. Limits of parental divergence for the occurrence of heterosis through morphological and AFLP marker in chilli (Capsicum annuum L.). Current science, Bangalore, v. 104, n. 6, p. 738-746, 2013.

LÉOTARD, G.; DUPUTIÉ, A.; KJELLBERG, F.; DOUZERY, E. J. P.; DEBAIN, C.; GRANVILLE, J. J.; MCKEY, D. Phylogeography and the origin of cassava: new insights from northern rim of the Amazonia basin. Molecular Phylogenetics and Evolution, Orlando, v. 53, n. 1, p. 329-334, 2009.

LIU, K.; MUSE, S. V. PowerMarker: an integrated analysis environment for genetic marker analysis. Bioinformatics Research Center, Raleigh, v. 21, n. 9, p. 2128-2129, 2005.

MANTEL, N. The detection of disease clustering and a generalized regression approach. Cancer Research, Baltimore, v. 27, n. 2, p. 209-220, 1967.

MBA, R. E. C.; STEPHENSON, P.; EDWARDS, K.; MELZER, S.; NKUMBIRA, J.; GULLBERG, U.; APE, K.; GALE, M.; TOHME, J.; FREGENE, M. Simple sequence repeats (SSR) markers survey of the cassava (Manihot esculenta Crantz) genome: towards an SSRbased molecular genetic map. Theoretical and Applied Genetics, Berlin, v. 102, n. 1, p. 21-31, 2001. 
MOURA, E. F.; FARIAS-NETO, J. T.; SAMPAIO, J. E.; SILVA, D. T.; RAMALHO, G. F. Identification of duplicates of cassava accessions sampled on the North Region of Brazil using microsatellite markers. Acta Amazonica, Manaus, v. 43, n. 4, p. 461-468, 2013.

MUHLEN, G. S.; ALVES-PEREIRA, A.; CLEMENT, C. R.; VALLE, T. L. Genetic diversity and differentiation of Brazilian bitter and sweet manioc varieties (Manihot esculenta Crantz, Euphorbiaceae) based on SSR molecular markers. Journal of the Society for the anthropology of lowland South America Tipití, v. 11, n. 2, p. 66-73, 2013.

NICK, C.; CARVALHO, M.; ASSIS, L. H. B.; CARVALHO, P. S. Genetic dissimilarity in cassava clones determined by multivariate techniques. Crop Breeding and Applied Biotechnology, Viçosa, MG, v. 8, n. 2, p. 104-110, 2008.

NICK, C.; CARVAlHO, S. P.; JESUS, A. M. S.; CUSTÓDIO, T. N.; MARIM, B. G.; ASSIS, L. H. B. Divergência genética entre subamostras de mandioca. Bragantia, Campinas, v. 69, n. 2, p. 289-298, 2010.

OLSEN, K. M. SNPs, SSRs and inferences on cassava's origin. Plant Molecular Biology, Dordrecht, v. 56, n. 4, p. 517-526, 2004.

PEAKALL, R.; SMOUSE, P. E. GenAlEx 6.5: genetic analysis in Excel. Population genetic software for teaching and research-an update. Bioinformatics, Oxford, v. 28, n. 19, p. 2537-2539, 2012.

PERONI, N.; KAGEYAMA, P. Y.; BEGOSSI, A. Molecular differentiation, diversity and folk classification of sweet and bitter cassava (Manihot esculenta) in Caiçara and Caboclo management systems (Brazil). Genetic Resources and Crop Evolution, Dordrecht, v. 54, n. 6, p. 1333-1349, 2007.

R CORE TEAM - R. A language and enviromment for statistical computing. Viena: R Foundation for Statistical Computing, 2013. Available at: <http://www.r-project. org >. Accessed at: 12 may 2015.

FOOD AND AGRICULTURE ORGANIZATION OF THE UNITED NATIONS - FAO. Save and grow cassava: a guide to sustainable production intensification. Rome: FAO, 2013. Available at: <http://www.fao.org/ docrep/018/i3278e/i3278e.pdf $>$. Accessed at: 6 may 2015 .
SIQUEIRA, M. V. B. M.; PINHEIRO, T. T.; BORGES, A.; VALLE, T. L.; ZATARIM, M.; VEASEY, E. A. Microssatellite polymorphisms in cassava landraces from the Cerrado Biome, Mato Grosso do Sul, Brazil. Biochemical Genetics, New York, v. 48, n. 9-10, p. 879895, 2010.

SOKAL, R. R.; ROHLF, F. J. The comparison of dendrograms by objective methods. Taxon, Bratislava, v. 11, n. 2, p. 33-40, 1962.

SOUZA, L. S.; FARIAS, A. R. N.; MATTOS, P. L. P.; FUKUDA, W. M. G. Aspectos socioeconômicos e agronômicos da mandioca. Cruz das Almas: CNPMF, 2006. 817 p.

VIEIRA, E. A.; CARVALHO, F. I. F.; BERTAN, I.; KOPP, M. M.; ZIMMER, P. D.; BENIN, G.; SILVA, J. A. G.; HARTWIG, I.; MALONE, G.; OLIVEIRA, A. C. Association between genetic distances in wheat (Triticum aestivum) as estimated by AFLP and morphological markers. Genetics and Molecular Biology, Ribeirão Preto, v. 30, n. 2, p. 392-399, 2007.

VIEIRA, E. A.; FIALHO, J. F.; FALEIRO, F. G.; BELLON, G.; FONSECA, K. G.; CARVALHO, L. J. C. B.; SILVA, M. S.; PAULA-MORAES, S. V.; OLIVEIRA, C. M.; DENKE, M. L. Characterization of sweet cassava accessions based on molecular, quantitative and qualitative data. Crop Breeding and Applied Biotechnology, Viçosa, MG, v. 11, n. 3, p. 232-240, 2011.

VIEIRA, E. A.; FIALHO, J. F.; FALEIRO, F. G.; BELLON, G.; FONSECA, K. G.; SILVA, M. S.; PAULAMORÃES, S. V.; CARVALHO, L. J. C. B. Caracterização fenotípica e molecular de acessos de mandioca de indústria com potencial de adaptação às condições do Cerrado do Brasil Central. Semina: Ciências Agrárias, Londrina, v. 34, n. 2, p. 567-582, 2013.

WEIR, B. S.; COCKERHAM, C. C. Estimating F-statistics for the analysis of population structure. Evolution, New York, v. 38, n. 6, p. 1358-1370, 1984.

ZUIN, G. C.; VIDIGAL-FILHO, P. S.; KVITSCHAL, M. V.; GONÇALVES-VIDIGAL, M. C.; COIMBRA, G. K. Divergência genética entre acessos de mandioca-de-mesa coletados no município de Cianorte, região Noroeste do Estado do Paraná. Semina: Ciências Agrárias, Londrina, v. 30, n. 1, p. 21-30, 2009. 